\title{
Critical Social Justice: The Moral Imperative for Critical Perspectives in Nursing
}

\author{
Elizabeth McGibbon, Sionnach Lukeman
}

\author{
Rankin School of Nursing, St. Francis Xavier University, 2340 Notre Dame Avenue, Antigonish, \\ Nova Scotia, Canada.
}

Cite as: McGibbon, E., \& Lukeman, S. (2019). Critical Social Justice: The Moral Imperative for Critical Perspectives in Nursing. Witness: The Canadian Journal of Critical Nursing Discourse, 1(1), 3-12. https://doi.org/10.25071/2291-5796.21

\begin{abstract}
There is increasing urgency to enact critical perspectives in the profession of nursing, with a resurgence of the political, a deliberative focus on social change, and a growing uneasiness with remaining neutral in the face of such pressing need. This analysis starts with a brief overview of critical perspectives, underscoring nursing's complex positioning at the interface of witnessing peoples' suffering, and the structural change necessary to address its root causes. Although witnessing may imply watching, or even bystanding, here it refers to historical and cultural meanings of witnessing as standing alongside in solidarity and action throughout the struggle for justice-bearing witness as a moral and a political obligation. Moral bystanding is described as a foundational barrier to achieving the moral imperative of critical perspectives. We conclude with pathways for cultivating and enacting a critical gaze, and a call for moral courage to systematically integrate critical perspectives in nursing. Throughout the discussion, we draw upon the work of nurse ethicists to provide important links about enacting critical perspectives as part of the moral foundation of nursing. Our intention is not to provide an analysis of the moral contexts of nursing, but rather to situate critical perspectives within the moral territory of social change, synthesizing key ideas that have direct salience for critical social justice in nursing.
\end{abstract}

Keywords: Critical social justice, critical perspectives in nursing, moral bystanding, nursing activism

There is increasing urgency to enact critical perspectives in the profession of nursing. Interrogating power relations is no longer a marginalized activity, ostensibly undertaken by outliers and the malcontent, which was the case not so long ago in nursing's history. There is also a resurgence of the political, a deliberative focus on social change, and a growing uneasiness with remaining neutral in the face of such pressing need. This analysis starts with an overview of critical perspectives, underscoring nursing's complex positioning at the interface of peoples' suffering, and the structural change necessary to address its root causes. We situate critical social justice in the context of critically analyzing its associated discourses, with an emphasis on language as a key site of power. Moral bystanding is described as a foundational barrier to achieving the moral imperative of critical perspectives. Specifically, moral bystanding is characterized as a violent act, whether or not it is the result of action or inaction. We conclude with pathways for cultivating and enacting a critical gaze, and a call for moral courage in systematically integrating critical perspectives in nursing. Although as authors our heritage is rooted in Ireland's Catholic

Corresponding Author: Elizabeth McGibbon, C271 Camden Hall, Rankin School of Nursing, St. Francis Xavier University, 2340 Notre Dame Avenue, PO Box 5000, Antigonish, Nova Scotia, Canada. Email: emcgibbo@stfx.ca 
working classes, we are currently positioned in society as white, able-bodied, well-educated heterosexual middle-class women. We also speak as critical social scientists, and we draw upon the work of nurse ethicists to provide important links about enacting critical perspectives as part of the moral foundation of nursing. Our intention is not to provide an analysis of the moral contexts of nursing, but rather to situate critical perspectives within the moral territory of social change, synthesizing key ideas that have direct salience for critical social justice in nursing.

\section{Critical Perspectives: Oppression, Power, Emancipation and Structural Change}

It is important to be clear about what we mean by critical perspectives, because the term, as it is used in nursing, does not necessarily invoke action for structural change. Critical perspectives, at least as a formal analytical tool, are based in part on critical social theory (Habermas, 1970), which emerged from resistance movements against social injustices such as fascism, colonialism, and racism. These perspectives center on questions about the genesis and maintenance of societal power hierarchies, including questions about access to knowledge production and the goods and services of society. Within this framework, issues of self, identity, power, economy, culture, and social justice are explicitly analyzed. Core features of a critical perspective, not necessarily in any particular order, are: 1) explicit analyses and critique of hegemonic power structures and ruling relations; 2) organized public protest and acts of resistance in the face of oppressive, often murderous, regimes, public policies, and the like; and 3) explicit goals of disrupting, unsettling, and interrupting, processes and practices of oppression in local and global spheres (all of which are synergistically connected).

The overall imperative is social change, which refers to structural change that confronts and eliminates oppressive processes and social injustices such as ableism, ageism, colonialism, ethnocentrism, genderism, heterosexism, racism, and sexism, to name a few. They are called structural because they are part of the political, economic, and social structure of society, and of the culture that informs them (Navarro, 2019). When we consider oppressions from a structural perspective, we are analyzing the role of systemic processes in the creation and maintenance of micro and macro aggressions associated with all of the isms. This structural violence is framed and organized by healthcare systems, legal systems, and many other societal systems and institutions (McGibbon, Bailey \& Lukeman, 2019). Critical perspectives challenge systemic injustice, and hence their direct links with critical social justice. The germinal work of Stevens (1992) provides a foundation for understanding critical perspectives, and her analysis sets the stage for the relevance of a renewed moral commitment to critical perspectives in nursing:

1. All research, theory, and practice are political because they are intimately affected by the social, economic, and political processes of the society;

2. Oppressive power relations are common in society; usually they operate without much notice and are taken for granted;

3. Scientific and practical ways of thinking and getting things done are open to systematic questioning and criticism;

4. Social, economic, and political conditions have a history;

5. One can better understand the changing conditions of society's health by studying the historical development of unsafe physical surroundings, oppressive social arrangements, economic inequities, and political disenfranchisement;

6. Liberation from oppressive environmental constraints is an indispensable part of any group's pursuit of wellbeing and integrity ( $\mathrm{p}$. 203).

Some of the most important critical perspectives in nursing include critical feminist perspectives, postcolonial perspectives, anti-racist perspectives, queer theory, transgender theory, feminist intersectionality theory, and critical disability studies. There is not a singular critical perspective, and critical perspectives, by virtue of their social change imperative, overlap, intertwine, and are continually evolving. The movement to decolonize nursing, for example, draws upon anti-colonial and anti-racist theories, Indigenous (First Nations, Metis, Inuit) standpoint theories and Indigenous epistemologies, and critical feminist theoretical perspectives (Anderson, 2002; Browne, Smye \& Varcoe, 2005; Gerlach, Browne, Sinha \& Elliott, 2017). Although largely distinct in their origins, feminism, anti-racism and post-colonialism share critical theory's focus on progressive social change to address systemic oppression. 
Critical race theories, in particular, "combine progressive political struggles for racial justice with critiques of the conventional legal and scholarly norms, which are themselves viewed as part of the illegitimate hierarchies that need to be changed" (Berkman Klein Center for Internet \& Society at Harvard University, 2019). Critical feminist sociology, particularly Dorothy Smith's (1987) institutional ethnography, continues to underpin important advances in nursing research (Campbell \& Kim, 2018; Rankin, 2017). Most recently, feminist political economy perspectives have begun to inform nursing critiques and analyses of neoliberal impediments to achieving justice, particularly in the area of health inequities (McGibbon \& Hallstrom, 2012; McGibbon \& Lukeman, 2019). Feminist political economy and Smith's critical feminist sociology are rooted in Marxist, materialist analyses that integrate how societal hierarchies of class relations condition most potently how other variables affect the population's health (Navarro, 2002). Critical perspectives are thus a core feature of enacting critical social justice, with the critical direction again pointing us toward naming, challenging and changing oppressive social, economic and political processes and regimes. Learning about the critique of misogyny, racism and socially constructed cultural prejudice and discrimination, is a central aspect of learning to change ourselves and to engage in progressive social change (Au, 2019).

Critical social justice is often framed simultaneously as social and political justice, with intervention and transformation in the actualities of peoples' everyday worlds (de Vira, 2018). Results include qualitatively and quantitatively measurable social change that supports dignity and justice for individuals and collectives of people, and for families, communities and nation states. Language is crucial because the term social justice, without its critical origins, is social justice "light". Hierarchies of power are always central, and the language we use organizes whether or not we are ready to interrogate this power. The discourse of social justice is itself a pivotal site of power, where language can both constrain or liberate social justice action. Critical discourse analysts have consistently emphasized "the way social power abuse, dominance and inequality are enacted, reproduced and resisted by text and talk in the social and political context" (Van Dijk, 2001, p. 352). Language becomes the terrain where nurses either support or resist ruling relations that operate to create and sustain oppression.
Rather than merely being a vehicle to express ourselves in text and talk, language is itself a mechanism that nursing often uses to support the status quo. When nursing practice and governance language gets stuck in "neutrality", "objectivity", and going-along-to-get-along, nurses are in fact deeply contributing to the texts and talk of dominant hierarchies.

Smith (1990) refers to these processes as the textual organization of power, where texts themselves are central instruments for maintaining authority and supremacy. She further describes how texts can be analyzed for their characteristically textual forms of participation in social relations of power:

Our interest is in the social organization of those relations, and in penetrating them, discovering them, opening them up from within, through the text. The text enters the laboratory, so to speak, carrying the threads and shreds of the relations it is organized by and organizes. The text before the analyst, then, is not used as a specimen or sample, but as means of access, a direct line to the ruling relations it organizes. (p. 4)

In nursing, textual organization includes the words and images we use and the persistent dominance of some voices over others. Nurses exercise textual power in their choices to omit justice and rights-based language, and replace it with lighter, squishier versions that do not reflect the moral urgency of tackling the suffering caused by oppression. Although actions such as advocacy, social support, and working for equity are all justice-related, unless we are enacting critical language (e.g. social pathogens social murder, neoliberalism, emancipation, liberation, Treaty rights, human rights), we are not talking about the imperative for change. If oppression is not a central aspect of the texts and talk of justice, then we are not in the structural realm, at least in terms of advancing structural change. This process is a conundrum for nursing because we must necessarily work at the pointy edges of suffering and safety in peoples' lives, and yet go well beyond this suffering to disrupt structures that cause the suffering in the first placeprivately and publicly taking a stance to draw upon nursing's moral underpinnings to tackle the causes-ofthe-causes. 


\section{Moral Bystanding as Violence}

In Germany, they first came for the Communists, and I didn't speak up because I wasn't a Communist. Then they came for the Jews, and I didn't speak up because I wasn't a Jew. Then they came for the trade unionists, and I didn't speak up because I wasn't a trade unionist. Then they came for the Catholics, and I didn't speak up because I was a Protestant. Then they came for me and by that time, no one was left to speak up. (Rev. Martin Niemuller)

Critical social justice is a natural extension of nursing ethics. Thompson, Melia, Boyd and Horsburgh (2006) define ethics as the collective belief-and-value system of any moral community, or social and professional group. Ethics and morality are often interchangeable, with Greek and Latin origins respectively referring to custom or habit (Storch, 2004). In the contexts of justice, nursing ethics involves the moral standpoints that inform nurses' personal lives as well as their professional practice to mitigate or halt injustice. In this discussion, we situate moral bystanding within the field of nursing ethics. Bystanding is a term that emerged in the context of violence against women, particularly sexualized violence. It refers to witnessing a transgression(s), while standing by and not intervening. Moral bystanding involves intentionally and unintentionally remaining silent when injustice is perpetrated. Nurses engage in moral bystanding when, through action or lack of action, they take a stance that fails to account for the resulting moral consequences. In other words, they individually and/or collectively fail to connect their actions, inactions, decisions, and processes to the human and ecological suffering that results from their bystanding. In nursing, bystanding involves cognitive dimensions, where moral reasoning and decision-making can inspire or inhibit action. Bystanding also involves the material, embodied action and inaction of nurses, often in the context of multidisciplinary teams.

A paramount demonstration of both of these dimensions of bystanding is the treatment of Mr. Brian Sinclair. In this case, moral bystanding had its underpinnings in systemic racism, a key finding of the Brian Sinclair Working Group (2017). Mr. Sinclair was a First Nations man who was also a doubleamputee. He went to the Health Sciences Centre in Winnipeg in 2008 complaining of abdominal pain and a catheter problem. According to the Sinclair family lawyer, "He was told to go and wait in the waiting room. He was never called back. Ever. He was ignored to death. He had a bladder infection. He just needed antibiotics and a catheter change. [At the inquest] the chief medical examiner said: "If the treatment had been given...he would not have died on that day", (Zbogar 2014: p. A9). Hospital staff, including nurses, walked past Mr. Sinclair many times and did not intervene. He vomited as he went into shock, and someone gave him a basin. This was the only medical intervention that was offered. The inquest revealed that some of the nursing staff assumed that he was drunk and "sleeping it off". Mr. Sinclair was left in distress and without the emergency care he needed for 34 hours. He died in the emergency department and was then ignored for several more hours until rigor mortis set in (Brian Sinclair Working Group).

Mr. Sinclair's story illustrates the everyday, embodied nature of moral bystanding in nursing. These events also underscore how nurses can cognitively and bodily participate in moral bystanding that involves racism, whether or not they are aware of their participation. Although there are many examples of light bearing leaders in nursing education, policy-making, practice and research, where critical perspectives are deliberatively and systematically integrated, significant moral bystanding still occurs. Interconnected examples include nursing education (e.g. resistance to curricular integration of critical perspectives on the social determinants of health (SDH), the political economy of health, or nursing's moral imperative for political action), policy-making (e.g. professional association and college reluctance to take a public and political stance on poverty and homelessness), practice (e.g. creating barriers to integration of the many facets of cultural safety, beyond definitions; or addressing the persistence of gender binary language), and research (e.g. white settler "objectivity" in the research process).

This lack of naming, analyzing and teaching about structural violence and oppression remains a troubling example of moral bystanding. In nursing education, for example, we often socialize nursing students in a culture of ignorance, with an emphasis on "skills and competencies", and this culture can be described as one of inherent and hidden violence. Freire (1970, 1993) refers to these kinds of processes as the banking system of education, an "approach to learning that is 
rooted in the notion that all students need to do is consume information fed to them by a professor and be able to memorize and store it" (hooks, 1994, p. 14). In the profession as a whole, we often reduce macro social and political concepts, such as the SDH, to a token, memorizable list, where we trivialize complex synergies among the SDH, and bypass what occurs in peoples' lives when the isms and spatial oppressions are also integrated. Freire (1993) further describes the banking system of education as an instrument of oppression. In nursing, this deeply embedded system tenaciously contributes to the profession's moral bystanding and inherent oppressive practices.

Critical perspectives are thus a key lens that can help expose and address moral bystanding across all spheres of nursing. However, in terms of enacting or living-in a critical perspective, nursing has troubling and persistent barriers. Feminist sociologist Judy Lorber (1994) stated that asking people to notice gender is like asking fish to notice water. Asking nurses to notice and hence critique the damaging impacts of Eurocentric biomedical hegemony, is also like asking fish to notice water. Over centuries, we have been, and still are, swimming in its waters. The biomedical version of empiricism is especially problematic because choices about where and how to even look for "facts and truths" are filtered through the lens of the isms. Nursing itself has its origins in white upper class Eurocentrism. Although we stand on the shoulders of these early nurse theorists, who sought to integrate women's intellectual power in a profession that was viewed as subservient and lacking in intellectual heft, they solidified a philosophical stance of positivism. This process is one of the reasons that it has taken nursing knowledge so very long to integrate theory and related pedagogy from the critical social sciences the humanities, and from Indigenous knowledge keepers.

The rhetoric of evidence-based practice, grounded in empiricism, also becomes open for scrutiny. Evidence according to which worldview? Evidence according to whose voice and whose ways of knowing? Empiricism, the dominant mode of thinking in nursing, supports the invisibility and erasure of critical perspectives, and the much-contested belief that objectivity is desirable and even possible. An interesting extension of problematizing biomedicine in the context of moral bystanding is that the health ethics field itself is also dominated by the reductionist thinking of empiricism and positivism. Although feminist and relational ethics are a distinct departure, biomedical hegemony persists. Objectivity is a concept that nursing borrowed (more akin to rented, because the cost has been so high) from positivist theoretical perspectives, especially those of medicine. Objectivity, or at least attempts to achieve objectivity, hampers our capacity for the intellectual curiosity necessary to sustain critical perspectives. This barrier often keeps us at the outside layers of the onion-we may peel off a few layers about individual differences and "diversity", but the messy layers of subjectivity, social location, and power-over, often elude us in many areas, including nursing's public discourse (e.g. conferences, position statements, peer-reviewed literature, textbooks).

The violent subtext of this process is that it creates and supports a stance of bystanding in the face of needlooking the other way when silence will support physical, spiritual, and psychological damage for humans, ecosystems, and all living creatures. This stance "scientifically" supports neutrality: "Someone else will speak up;" "So-and-so always takes this issue on, and there is no need for me to speak up"; "I was in the room, but it wasn't my fault because I didn't have a vote"; or perhaps most egregiously, "I prefer to remain neutral when these kinds of controversies come up at work". The consequences are grave because there is no neutral seat on a moving train. In other words, nurses' moral compass is always active, whether or not our moral choices involve action or lack of action. Consider being on a train that is moving dangerously fast and we are asked to help slow down the train. We say that we would rather remain neutral and let someone else take action. Our inaction thus becomes a powerful action that contributes to the possible crashing of the train.

Although moral bystanding is cloaked in ostensible objectivity and neutrality, it involves decisions to actively engage in bystanding. A relatively common expression in the Eurocentric Western world is "theelephant-in-the-room". It refers to situations where people engage in discussion while avoiding a very large idea, problem, or event that is at the heart of their discussion. Even though this elephant is in the middle of the room, people take great lengths to ignore it. If anyone initiates morally situated truth telling about the elephant, they may be accused of a number of infractions, such as "being too negative," "taking 
things too seriously", "being biased", "being too political", and ironically, "not wanting to support change". These comments silence talk about the elephant-in-the-room, and become an overt discursive tactic to suppress resistance. Another important current example is the beaver-in-the-room, where the beaver symbolizes historical and ongoing colonization and imperialism. The beaver is a fitting analogy because the beaver brings to mind both sides of the racist, colonial coin - as one of the central living creatures in Indigenous lifeways across time, and as one of the icons of colonial imperialism in the territories we now call Canada. In nursing, moving beyond bystanding for truth and reconciliation involves critically naming the beaver-in-the-room. These two analogies - the elephant and the beaverillustrate how moral bystanding, by actively doing nothing, results in the creation and maintenance of structural violence. Moving forward to address, rather than support this violence, means extending social justice action to explicitly integrate the moral underpinnings of activism.

\section{Catalyzing Moral Pathways for Activism}

Nursing has been criticized for its lack of political action and voice regarding important issues related to public policy for health. It is disturbing that the combination of the number of nurses in Canada, coupled with our trusted reputation, has not translated into power and influence over structural and political determinants of health, especially in comparison to physicians (Lewis, 2010). Daily, nurses navigate the tensions between public policy and the intimate personal lives of individuals and families, a unique role that presents the moral obligation to effect social change and political action in practice (Falk-Rafael, 2005). Bearing witness to human suffering is a privileged position, but this witnessing necessarily comes with immense responsibility. Although witnessing may imply watching, or even bystanding, here it refers to historical and cultural meanings of witnessing as standing alongside in solidarity and action throughout the struggle for justice: “...bearing witness in nursing practice is most usefully conceptualized as both a moral and a political obligation (Djkowich, Ceci \& Petrovskaya, 2019, Abstract). Addressing the social, economic and political policies and structures responsible for this suffering requires the opportunity for nurses and nursing students to engage in deep critical analysis and reflection of their position and role (Falk-Rafael, 2005).

Discomfort with activism is deeply rooted, and neoliberal dynamics in healthcare and higher education have created a toxic environment for developing nurses' activist practice (Buck-McFadyen \& MacDonell, 2017). In healthcare reform, neoliberal principles, such as a focus on efficiency and free market principles, privatization and corporatization, have deeply impacted nursing practice. Replacement of Registered Nurses with practical nurses has contributed to problematic and sometimes intolerable working conditions, such as insufficient staffing to maintain patient safety, and coercion to work overtime (Buck-McFadyen \& MacDonell, 2017; Duncan, Rodney \& Thorne, 2014). In 2016, public sector nurses worked 15.2 million hours of paid overtime and 4.9 million hours of unpaid overtime, which cost $\$ 968$ million - enough money to hire more than 11,000 fulltime nurses (Jacobson Consulting Inc., 2017). Nursing educators report similar impacts due to the corporatization of universities, and hence their time and energy for political action, such as increasingly large class sizes, lack of job security, increasing numbers of part-time faculty, and the adoption of the American-based National Council Licensure Examination (NCLEX).

Amidst these complex contexts, nursing's challenge is to extend and enrich a renewed commitment to social change - a commitment grounded in moral courage. Moral courage involves true presence, which may be interpreted in the sense of mindfulness practice; moral integrity; honesty; advocacy; and personal risk (Numminen \& Leino-Kilpi, 2017). Important antecedents of moral courage are ethical sensitivity and conscience (Numminen \& Leino-Kilpi, 2017)when we pay attention to our own personal moral compass, and speak up when our conscience tells us that something is unethical. Rodney and Street (2004) described how ethics leaders in the nursing community have an opportunity to establish a moral community, a place where nurses initiate action to translate ethical principles into compassionate practice. The teachings of nurse ethicists can provide these pivotal links among committing to critical perspectives and enacting social justice. Enacting moral agency, for example, is at the core of taking deliberate action to grow beyond the bystander role, "opening a critical space for dialogue and self-reflection" (van Wijlen, 
2017, p 18). Doane and Varcoe (2014) describe how nurses can collectively become involved in an ongoing process of inquiry that focuses on looking through a critical lens using multiple filters. This process supports nurses as they systematically position their social location and their beliefs in their practice. According to Peter (2011), within feminist relational ethics approaches,

...it is possible to think of moral agency as more than a characteristic possessed by an aggregate of individuals. It is possible to think of agency as a relational or socially connected characteristic of individuals in such a way that we can, at least to some extent, recognize, reflect on, and act on moral responsibilities as a collective. (p. 12)

Tenured faculty can take the lead in orienting curriculums towards the moral courage necessary to integrate critical perspectives across all years of undergraduate and graduate education. Unionized senior practitioners in clinical settings can take the lead to ensure mandated education about the many forms of stereotyping and discrimination in practice, as well as specifically planned continuing education that is tethered to institutional accreditation benchmarks. These examples illustrate some of the moral complexities of enacting a critical perspective. Rodney, Brown and Liashenko (2004) describe the centrality of power in nurses' moral agency, where asymmetries of power can deeply constrain action on the part of nurses, as well as the people with whom they work (e.g. patients, families, communities, nations). It is important to note that although nurses may recognize injustice, speaking up or taking action is not always possible, depending on nurses' own identities and oppressive circumstances, and constraints in their practice. Carnevale (2013), in particular, describes how nurses' moral distress can be a marker of conscientious moral engagement with their professional practice. Enacting critical perspective requires meticulous attention to individual and collective barriers to moving forward, and recognition that developing a critical gaze for action is an ongoing and iterative process. The following strategies can support pathways for this action.

\section{Box 1, Pathways for Cultivating and Enacting Critical Perspectives}

Taking sides Neutrality is situated in the perilous territory of agreeing with oppression. If we do not speak up, we are silently agreeing. In reference to South African Apartheid atrocities, Bishop Desmond Tutu famously stated: "If you are neutral in situations of injustice, then you have chosen the side of the oppressor. If an elephant has its foot on the tail of a mouse, and you say that you are neutral, the mouse will not appreciate your neutrality" (2009).

Acting in solidarity Acting with unanimity, cooperation, mutual support, and cohesion- "engaging in a critical and committed way with communities and social movements for progressive social change" (Emejulu, 2008, p.32).

Taking risks Exploring the ways that problems are defined and framed by dominant voices, challenging taken for granted ways of thinking, exposing hidden power agendas in public policy-making. Mapping places, spaces, and forms of power (See Gaventa's Power Cube, Gaventa, 2006).

Developing political literacy Knowing and applying the policy cycle (See From Policy to Action, Ellen \& Shamian, 2011), and understanding how politics and policy are connected. Knowing your political compass and the political compasses of the major political parties (See Political Compass, Pace News Ltd, 2019).

Working at the grassroots "Being in everyday contact with people on their own ground and on their own terms" (Emejulu, 2008, p.32), building on participatory action that is already strong in key areas of nursing.

Listening to dissenting voices Valuing, rather than suppressing dissent. Creating spaces in which different and opposing interests are expressed, and voices are heard. This pathway will necessarily mean that nurses - and the profession as a whole - take action to confront and address the gendered nature of voice in nursing. 
Cultivating awkwardness "Democracy is not necessarily best served by the conformist citizen. This means that the educational task is to create situations in which people can confront their circumstances, reflect critically on their experience and take action" (Emejulu, 2008, p.32).

Educating for social change Analyzing our own location on the social change continuum, from actively participating in oppression, to taking public action to name, dismantle and prevent ruling societal systems that create and sustain social injustice (See Social Change Continuum, in McGibbon, 2017).

Exploring alternatives "Seeing that the status quo is not inevitable - that another world is possible" (Emejulu, 2008, p.32).

Exposing the power of language Taking great care to name and analyze taken-for-granted ways that language dictates beliefs and values, and thus our action or lack of action. If the discourse (texts and talk) of oppression is not front and center, then we are most likely sidestepping critical perspectives and hence opportunities for collective moral engagement and change.

Developing a moral community for social justice Linking the field of nursing ethics with enacting social justice. Although these links already exist, nurses can more systematically draw upon the work of nurse ethicists to explicitly inform critical social change in the nursing community.

Source: Adapted from Emejulu, A. (2008). Learning for democracy: Ten propositions and ten proposals. In Reclaiming purpose in community education: The Edinburgh Papers 2008. Edinburgh: University of Edinburgh.

\section{Conclusion}

The continued relevance for nursing as a contemporary profession rests on our capacity to integrate critical perspectives through leadership in education, policy-making, practice and research. If we, as a collective, continue to see justice as primarily the responsibility of other people (e.g. other professions, groups, political activists), we may become irrelevant in the critical social science of health, especially given neoliberal roadblocks to social democracy in healthcare. Over and above the sustainability of the profession, our main catalyst is the moral imperative for enacting critical perspectives, and hence, critical social justice. Lila Watson, an Australian Indigenous woman, responded to mission workers by saying to them: "If you have come to help me, you are wasting your time. But if you have come because your liberation is bound up with mine, then let us walk together." Oppressions inscribed at the structural level in healthcare are, in fact, at the heart of the discipline's own identity as "powerless". Taking up the challenge of activism will necessarily catalyze critical perspectives about the social and political location of the profession itself.

\section{References}

Anderson, J. M. (2002). Toward a post-colonial feminist methodology in nursing research exploring the convergence of post-colonial and feminist scholarship. Nurse Researcher, 9, 720 .

$\mathrm{Au}, \mathrm{W}$. (2019). A Marxist education: Learning to change the world. Chicago: Haymarket Books.

Berkman Klein Center for Internet \& Society at Harvard University (2019). Critical race theory. Retrieved from:

https://cyber.harvard.edu/research/bridge

Browne, A., Smye, V., \& Varcoe, C. (2005). The relevance of postcolonial theoretical perspective to research in Aboriginal health. Canadian Journal of Nursing Research, 37, 1637.

Brian Sinclair Working Group (2015). Out of sight: Interim report of the Sinclair Working Group. Winnipeg: Brian Sinclair Working Group. Retrieved from: http://ignoredtodeathmanitoba.ca/index.php/ 2017/09/15/out-of-sight-interim-report-ofthe-sinclair-working-group/ 
Buck-Mcfadyen, E., \& Macdonnell, J. (2017). Contested practice: Political activism in nursing and implications for nursing education. International Journal of Nursing Education Scholarship, 14(1), 1-13.

Campbell, M. \& Kim, E. (2018). The (missing) subjects of research on gender and global governance: Toward inquiry into the ruling relations of development. Business Ethics, 27(4), 350-360.

Carnevale, F. (2013). Confronting moral distress in Nursing: recognizing nurses as moral agents. Revista Brasileira de Enfermagem, 66, 3338.

de Vira, A. (2014). Critical theory and social justice. Brazil Political Science Review, 8(1), 109126.

Djkowich, M., Ceci, C. \& Petrovskaya, O. (2019). Bearing witness in nursing practice: More than a moral obligation? Nursing Philosophy, 20, e12232. https://doi.org/10.1111/nup.12232

Doane, G.H. \& Varcoe, C. (2014). How to nurse: Relational inquiry with individuals and families in shifting contexts. New York: Wolters Kluwer.

Duncan, S., Rodney, P.A., \& Thorne, S. (2014). Forging a strong nursing future: insights from the Canadian context. Journal of Research in Nursing, 19(7-8), 621-633.

Ellen, M. \& Shamian, J. (2011). How we move beyond a policy prescription to action. Healthcare Papers 11(1), 76-83.

Emejulu, A. (2008). Learning for democracy: Ten propositions and ten proposals. In Reclaiming purpose in community education: The Edinburgh Papers 2008. Edinburgh: University of Edinburg. Retrieved from: https://criticallychatting.files.wordpress.com /2008/11/theedinburghpapers-pdf.pdf

Falk-Rafael, A. (2005). Speaking truth to power: nursing's legacy and moral imperative. Advances in Nursing Science, 28(3), 212223

Freire, P. (1970, 1993). Pedagogy of the oppressed. London: Continuum International Publishing Group Inc.
Gaventa, J. (2006). Finding the spaces for change: A power analysis. Institute of Development Studies Bulletin, 37(6). Retrieved from: https://www.powercube.net/wpcontent/uploa ds/.../finding_spaces_for_change.pdf

Gerlach, A.J., Browne, A. J., Sinha,V., \& Elliott, D. (2017). Navigating structural violence with Indigenous families: The contested terrain of early childhood intervention and the child welfare system in Canada. The International Indigenous Policy Journal, 8(3). Retrieved from: https://ir.lib.uwo.ca/iipj/vol8/iss3/6

Habermas, J. (1970). Toward a rational society: Student protest, science, politics. Boston: Beacon Press.

hooks, b. (1994). Teaching to transgress. Education as the practice of freedom. New York: Routledge.

Jacobson Consulting Inc. (2017). Trends in own illness- or disability-related absenteeism and overtime among publicly-employed Registered Nurses: Quick Facts 2017. Ottawa: Canadian Federation of Nurses Unions. Retrieved from www.nursesunions.ca/wpcontent/uploads/2017/05/Quick_Facts_Abse nteeism-and-Overtime-2017-Final.pdf

Lewis, S. (2010). So many voices, so little voice. Canadian Nurse, 106(8), 40.

Lorber, J. (1994). Paradoxes of gender. New Haven: Yale University Press.

McGibbon, E. (2017). The social determinants of health: Embodied oppression across the lifecourse. In Antony W. \& Antony, J. (Eds.), Power and resistance: Critical thinking about Canadian social issues, 6th Edition (pp. 165-194). Halifax: Fernwood Publishing.

McGibbon, E., Bailey, A., \& Lukeman, S. (2019). Violence and health: A structural perspective. In J. Etowa \& C. van DalenSmith (Eds.), Canadian Community Health Nursing (pp. 503-520). Toronto: Pearson.

McGibbon, E. \& Lukeman, S. (2019). Political economy perspectives and the moral imperative for justice activism in nursing. Paper accepted for presentation. Atlantic Region Canadian Schools of Nursing, June, 2019. 
McGibbon, E. \& Hallstrom, L. (2012). Oppression and the political economy of health inequities In E. McGibbon (Ed.), Oppression: A social determinant of health (pp. 167-185). Halifax: Fernwood Publishing.

Navarro, V. (2019). Why the white working-class mortality and morbidity is increasing in the United States: The importance of the political context International Journal of Health Services, 49(2), 197-203.

Navarro, V. (2002). The political economy of social inequalities: Consequences for health and quality of life. New York: Baywood Publishing.

Numminen, O., Repo, H., \& Leino-Kilpi, H. (2017). Moral courage in nursing: A concept analysis. Nursing Ethics, 4(8), 878-891.

Pace News Ltd. (2019). The political compass. Retrieved from: https://www.politicalcompass.org/

Peter, E. (2011). Fostering social justice: The possibility of a socially connected model of moral agency. The Canadian Journal of Nursing Research, 43(2), 11-7.

Rankin, J. (2017). Conducting analysis in institutional ethnography: Guidance and cautions. International Journal of Qualitative Methods, 16(1), 1-11.

Rodney, P., Brown, A., \& Liashenko, J. (2004). Moral agency: Relational connections and trust. In J. Storch, P. Rodney \& R. Starzomski, (Eds.), Towards a moral horizon: Nursing ethics for leadership and practice (pp. 154-171). Toronto: Pearson Canada.

Rodney, P. \& Street, A. (2004). The moral climate of nursing practice: Inquiry and action. In J. Storch, P. Rodney, \& R. Starzomski, (Eds.), Towards a moral horizon: Nursing ethics for leadership and practice (pp. 209-224). Toronto: Pearson Canada.

Ryan, J. \& Rottman, C. (2007). Educational leadership and policy approaches to critical social justice. Journal of Educational Administration and Foundations, 18(1-2), 9-23.

Smith, D. (1990). Texts, facts, and femininity: Exploring the relations of ruling. London: Routledge.

Smith, D. (1987). The everyday world as problematic: A feminist sociology. Boston: Northeastern University Press.

Stevens, P. (1992). Applying critical theories to nursing in communities. Public Health Nursing, 9(1), 2-9.

Storch, J. (2004). Nursing ethics: Developing a moral terrain. In J. Storch, P. Rodney \& R. Starzomski, (Eds.), Towards a moral horizon: Nursing ethics for leadership and practice. (pp. 1-16). Toronto: Pearson Canada.

Thompson, I., Melia, K., Boyd, K., \& Horsburgh, D. (2006). Nursing ethics. London: Churchill Livingston.

Tutu, D. (2009). The secrets of a peacemaker. The Guardian, Saturday, May 23, 2009.

Van Dijk, T.A. (2001). Critical discourse analysis. In D. Tannen, D. Schiffrin \& H. Hamilton (Eds.), Handbook of Discourse Analysis (pp. 357-71). Oxford: Blackwell.

van Wijlen, J. (2017). Healing the healer: A caring science approach to moral distress in new graduate nurses. International Journal for Human Caring, 21(1), 15-19.

Zbogar, V. (2014). Brian Sinclair's death was a homicide: But call it whatever you want, just address the discrimination. Winnipeg Free Press Print Edition, June 16, 2014, A9. 